get rid of all difficulty; for to infect the brain the septic material must first have been carried to the right side of the heart, sent through the lungs, returned to the heart, and then propelled to the brain.' But how did it pass through the lungs without leaving pyæmic abscesses there to attest the route of its progress? We know that in ordinary cases of pyæmia the lungs are prone to be the seat of metastatic abscesses. Why should they escape in such cases as this? Is it because particles not fine enough to escape arrest in the brain are yet able to pass through without lodging in the lungs, or because cerebral tissue is in some cases more apt to take on inflammatory action? If the latter, it may be that the long-continued suppuration of the empyema may induce a more than ordinary liability to suppuration in the brain. But these are matters of speculation.

Finally, as to treatment. I need hardly say that the question of surgical interference was discussed more than once. One thing in its favour was that there was little difficulty in saying where the seat of the abscess would be found. The symptoms noted during life pointed to the neighbourhood of the fissure of Rolando. But there were other points to be taken into consideration. First, the contents of the abscess might not have been so liquid as to have been readily removed when found, resembling, perhaps, more a diffused softening than completely formed pus. Secondly, the progress and extent of the paralytic symptoms led to the belief that a large area of brain was involved, to which probably permanent damage had been done, and even if the dangers of the operation itself had been safely surmounted, the ultimate prospects were not encouraging. Notwithstanding these considerations, however, I regret that the evacuation of the abscess was not attempted, although, perhaps, the result would have been of more advantage to medicine than to the patient himself.

\section{DRY DRESSINGS FOR INTERNAL CAVITIES. ${ }^{2}$}

Br CHARLES F. HUTCHINSON, M.D., MEDICAL OFFICER TO THE ROYAL NORTHERN SEA-BATHING INFIRMARY, SCARBOROUGH.

DRY dressings being now all the fashion, and to my mind most justly so, I wish to draw the attention of the profession to a very simple method of applying, in the dry state, dressings, styptics, \&c., to such cavities as the vagina, uterus, and rectum.

The only apparatus required is a hollow cacao-butter suppository, which suppositories are made in various sizes, the largest of which will just about hold one drachm of any ordinary powder. These hollow suppositories are filled with the powder that may be wished to be used as a dressing; the small lid, after being gently heated, is put on; this when cool remains fixed, and the whole apparatus is then ready to be introduced into the vagina or rectum. The heat of the body soon melts the cacao butter, and the powder is then brought, in as dry a state as possible, into direct contact with the parts. During the last six months I have used these suppositories most freely, and have, been more than satisfied with the result. I have tried all sorts of powders, and as the result of my own experience strongly recommend the following, either alone or in various combinations as required.

Firstly, as a styptic I most strongly recommend powdered iron-alum. I generally order one drachm of powdered ironalum and five grains of iodoform, to be well mixed together, the powder to be inserted into a hollow suppository and used as directed. In the treatment of uterine hæmorrhage I am convinced there is no remedy of more universal application, and none on which I could with greater confidence rely. I have used it in severe hæmorrhage from uterine fibroid, from uterine polypus, from uterine cancer, bad miscarriage, and in several cases of menorrhagia at the change of life, and it has never yet failed me. All that is required is to introduce the suppository as high as possible into the vagina, and there leave it. It is as easily applied by the nurse as by the doctor, and is in every way perfectly safe and harmless.

1 There is always, of course, the alternative previously referred to and preferred by Dr. Broadbent, of thrombus by the direct route of the pulmonary vein ; but this would not cover the case of the divided rib-ends. 2 Read before the Leeds and West Riding Medico-Chirurgical Society.
Secondly, as a dressing iodoform stands pre-eminent; in fact, I now seldom use anything else. This, when combined with from a quarter to half a grain of morphia, forms by far the best dressing for uterine cancer that 1 have yet tried.

Thirdly, morphia, either alone, or, as I generally now use it, in combination with either or both of the above, is a great aid to the physician and comfort to the patient.

After attention has once been drawn to this simple mode of applying these various applications, the numerous uses to which they might be put in the various vaginal, uterine, and rectal discharges and diseases will occur to all I have only very briefly ventured to suggest the use of those which in my own hands I have found deserving of confidence. I have no doubt that hundreds of the profession are at present using this mode of dressing; but, on the other hand, I know that there are hundreds who are not, and it is to persuade those who have not yet tried them that $I$ venture to bring this subject forward.

\section{d d dithror}

\section{HOSPITAL PRACTICE, BRITISH AND FOREIGN.}

Nulla autem est alia pro certo noscendi via, nisi quamplurimas et morborum et dissectionum historias, tum aliorum tum proprias collectas habere, et inter se comparare.-MorGagni De Sed. et Caus. Morb. lib. iv. Procemium.

\section{CHARING-CROSS HOSPITAL.}

TRANSVERSF FRACTURE OF THE LEFT PATELLA; OPERATION; CURE.

(Under the care of Mr. J. Astuex BloxaM.)

THE question as to the best treatment in cases of fracture of the patella is one which still occupies the attention of practical surgeons: whether to treat the fracture by means of splints, strapping, Malgaigne's hooks, or other apparatus, or to operate, as in this case, sewing the fragments together, using strict antiseptic precautions and drainage. Could the element of danger which follows a compound fracture in which the knee-joint is opened, even under such precautions, be eliminated, as it has not yet fully been, no doubt in healthy subjects this cause of immediate operation would be generally accepted. This patient recovered, with a limb the utility of which is hardly impaired, and the success obtained with close union of the fragments is much better than after the employment of the apparatus in ordinary use, excepting in a few isolated instances.

Walter T_- aged twenty-five, a carpenter, was unloading a van on July 19th, and on getting down he caught his heel between two pieces of wood and was thrown off the cart on to an iron grating in the roadway. He distinctly remembers hearing something snap, and on trying to rise was unable to do so. He was brought to the hospital and found to have fractured his left patella transversely. On admission. a back splint was applied, the leg bandaged, and the patient put to bed, an ice-bag being kept applied to the joint, which felt hot, and was somewhat swollen and tender.

July 24 th. - This afternoon Mr. Bloxam made an incision two inches and a half in length immediately over the patella, opening up the bursa and clearing out the blood and clots. He then separated the anterior surface of the patella from the aponeurotic tissue, and a hole was then drilled through the upper fragment obliquely from above downwards, and a similar one in the lower fragment in the opposite direction. A piece of stout silver wire was then passed through the holes and tightened, and the edges of the fractured patella brought into close apposition. A counter-opening was made to the outer side of the kneejoint, and a drainage-tube inserted. The edges of the incision were then stitched together with silver wire sutures, another drainage-tube being inserted. The whole operation was performed antiseptically, and the limb placed on a long back splint and slung.

25th.-Patient passed a restless night, and was given a onegrain opium pill at 8 P.M. and again at 12. He has no pain in the knee. Temperature $1008^{\circ}$. 